УДК 821.163.41.09 Јакшић, Ђ. https://doi.org/10.18485/msc50.2019.1.ch36

Радослав Јосимовић

\title{
МУЗИЧКО-СЛИКАРСКИ ЕЛЕМЕНТИ У УМЕТНОСТИ ЋУРЕ ЈАКШИЋА
}

Ђура Јакшић припада без сумње плејади европских романтичара полифонијског типа. Можда бисмо претерали ако бисмо га назвали genius multiplex, име које заслужују Иго, Колриџ, Делакроа, Блејк. Али сигурни смо да га можемо сматрати амбивалентним дивом, како су то истакли неки наши научници и уметнички критичари. О тој двострукости - ми ћемо говорити и о трострукости - његовог снажног талента већ је писао његов први биограф Светислав Вуловић, полазећи свакако од једног Ђуриног писма Ђорђу Поповићу:

„Знаш ли што сам намислијо моловати да кад тамо дођем имате шта и видети? Смрт Црнога Ђорђија. Ал’ опет незнам само тако мислим! Видећемо - ако то не намолујем, а ја ћу опевати, држим е би ваљан комад бијо."

Међутим, ако је Вуловић погрешио рекавши да је „између 1851. и 1853. пропао у Ђури ђенијалан сликар", један део модерне књижевне и уметничке критике данас све више открива Јакшићеву сликарску величину. Појединци су чак спремни да Ђуру pictora ставе изнаде поете. А већина виде ту стваралачку двојност у органском јединству. Академик и књижевник Глигорић је то поводом сликарске изложбе у САНУ 1971. лаконски истакао: „Сликар у поезији, песник у сликарству. Нераздвојни су песништво и сликарство у његовом стварању”.

Слично ће написати професор и уметнички критичар Лазар Трифуновић, поводом 100-годишњице смрти трагичног Таорина: „У Јакшићу се сликар и песник нису сукобљавали већ прожимали и допуњавали, јер су за њега поезија и сликарство два облика једне суштине".

Ове две тачне констатације нису још увек детаљније илустроване нити је Ђурино музичко-сликарско својство дубље осветљено. Наиме, поред мелодиозности у Јакшићевој поезији постоји и једна инхерентна музичност, чак се може говорити и о музичкој структури појединих пе- 
сама, као што и Јакшићева пиктуралност није једнозначна, ни у сликарству, ни у поезији.

Када говоримо о та три вида Јакшићеве уметности, ваљало би имати на уму ону танану Новалисову опаску: „поезија у строжем смислу речи изгледа као посредна уметност између ликовних и музичких уметности. Да ли можда такт одговара фигури, а звук боји?”

И данашњи многи песници слично мисле. Сетимо се, на пример, Коктоовог тумачења да је поезија суштина свих уметности. Са тих разлога ваљало би се мање задржавати на спољним облицима сликовитости и мелодиозности песама, а више на музичким структурама, на слојевитости слика и њиховим дубинским значењима. Наравно, за то треба много више времена и простора. За ову прилику учинићемо што можемо, у духу слогана Гијома Оранског: „als ik kan”.

Говорити о елементима музике у песништву и сликарству Ђуре Јакшића, изгледа на први поглед мало исфорсирано јер се може приметити да бунтовни уметник није имао готово никакве музичке културе. Формално не. Али не треба заборавити да сваки велики стваралац, како је истакао Бодлер, има у себи три природна својства: пиктуралност, аудитивност и олфактичност.

Своја пикторска својства Ђура је мукотрпно развијао у свом родном месту, код Константина Данила, у Бечу где је највише учио студирајући велике сликаре по галеријама, нарочито Рембранта. Што се тиче музике, ваља се сетити да је „умилно пјеније” слушао од свог оца свештеника, да је растао у једној средини у којој су људи били природно музички обдарени. Ђачке и позоришне дружине веома су неговале хорско певање и свирање на народним инструментима. Јакшић је могао да слуша како се у народу певају Трлајићеве композиције, Орфелинове песме. Музиколог Стана Ђурић-Клајн с правом говори да су не само писци XVIII већ и XIX века у Војводини, били веома музикални. Ваља такође имати на уму да је Беч 60-тих година прошлог века био „уметничка и духовна метропола словенског југа", када су у њему боравили, поред осталих, млади панчевачки, врло талентовани, виолонист Драгомир Кранчевић, затим славни композитори: Корнелије Станковић, Даворин Јенко, Зајц и др. Зар Јакшић није можда слушао од својих пријатеља, тамо 61. или 62. године о славним концертима поменутог Кранчевића у Бечу, Новом Саду, Панчеву? А сигурно му је било познато колико је Бетовенова музика била популарна не само у Бечу већ и у Новом Саду. Њу је могао слушати и у „женском заведенију” Спачекових, где је и сам једно време предавао ученицама, које су „умилно знале ударати у фортепијано”. 
Но несрећном Ђури Јакшићу „фортуна прасица”, како би рекао Марин Држић, стално је окретала леђа. Па кад је Нови Сад 1872. године био у еуфорији слушајући младу пијанисткињу Јованку Стојковић како свира Бетовенову Месечеву сонату, јадни Таорин се потуцао тада без службе у Пожаревцу. Судбина га је осудила да готово самоучки продире у тајне музике, сликарства и поезије, спајајући их интуитивно у велелепне синтезе. Он није знао теоријски да објасни, попут Гетеа, шта су то „латентне мелодије”, нити да развија теорију боја (Farbenlehre) ни звука (Tonlehre). Али све је то претежно хватао „на ухо”, али „ухо” које је умело такорећи да разазнаје нијансе тишина и да буде у дослуху са духом природе. Отуда и код Јакшића свака поетска реч је штедра бојом и звуком, засочена сталним бунтарством, који његовим песничким нитима дају више дурски а мање молски призвук. Судари супротности код Јакшића су се најчешће разрешавали у једној вишој људској равни. Ове две тачне констатације нису још увек детаљније образложене; још мање повезаност музичкосликарског елемента изучена. Ти су односи остали фрагментарно, а код неких и површно осветљени. Као да се заборавило да је музика „душа” поезије. А кад говоримо о овим својствима Јакшићеве уметности, ваљало би имати на уму ону Новалисову опаску: „Поезија у строжем смислу речи изгледа готово као посредна уметност између ликовних и музичких уметности. Да ли можда такт одговара фигури, а звук боји"?

Ако пак у поезији као специфичној синтези речи, звука и боје, желимо да истражујемо њене стратуме, а то је главни задатак сваке комплексне анализе, онда нећемо се задржавати на формалним вредностима речи, њиховим спољним облицима, на боји и маси по себи, ни на звучању, које бисмо крстили мелодиозношћу или пријатном ритмичношћу, већ ћемо трагати за унутарњим музичким структурама које скривају поетске еманације, за специфичностима њихове обојености, које органски сливене сачињавају непоновљиву уметничку лепоту.

За ову прилику задржаћемо се на неким, можда најкарактеристичнијим примерима Јакшићеве поезије, који скривају унутарње музичке и сликарске валере. Почнимо са песмом Спомен. Није тешко запазити да она личи на музичку дводелну песму састављену од два периода. У њој уочавамо унутрашње јединство које се организује око једног стожерног мотива постхумног сећања. И управо зато читава песма је дата у двочетвртинском такту, у темпу marcia funebre. Графички и музичким нотама изражена ова би песма изгледала овако: 


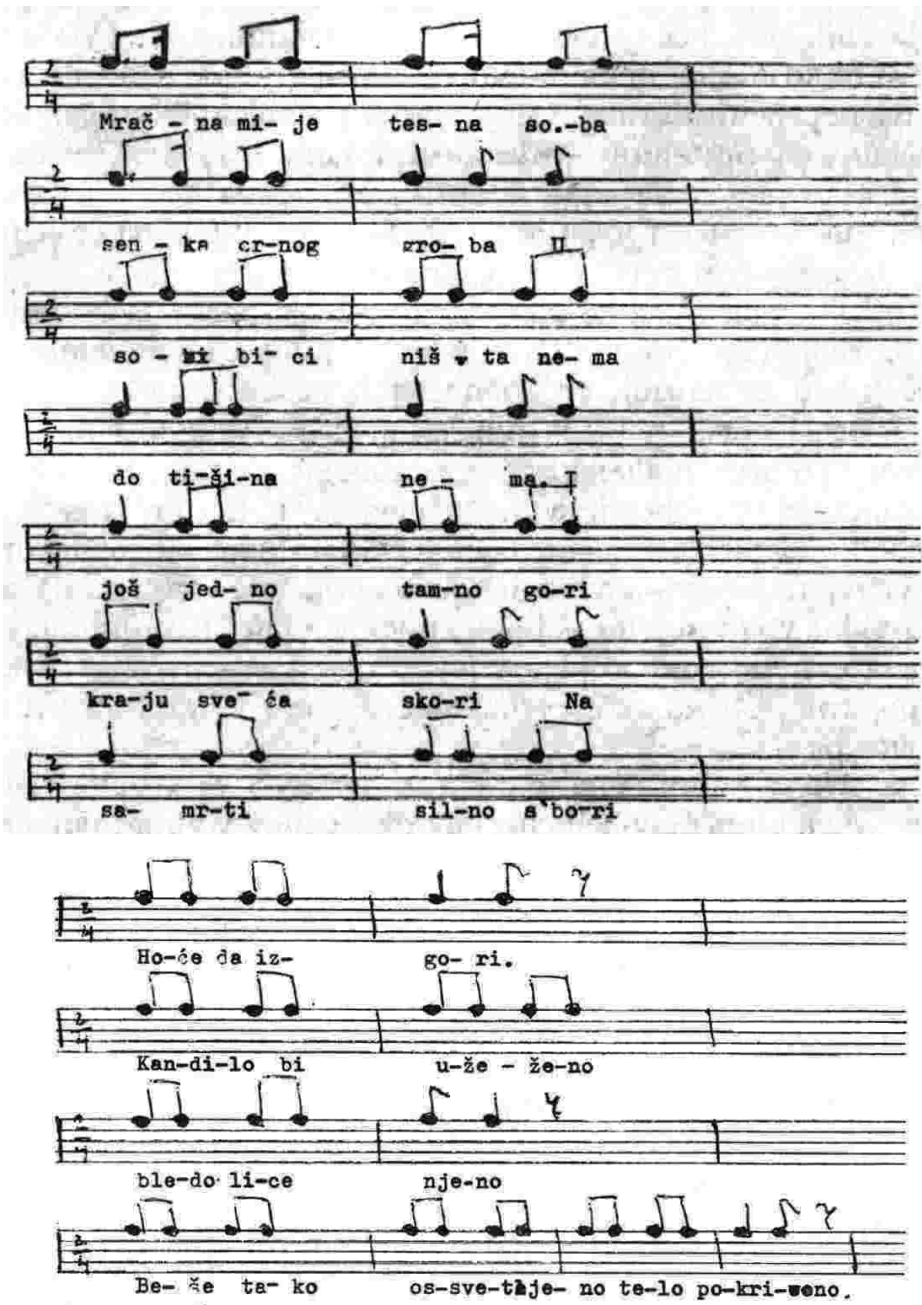

Запажамо такође да сваки други стих ове песме, у зависности да ли почиње једносложном или вишесложном речју, има на крају осминску паузу или ауфтакт. Јакшић је без сумње осетио инстинктивно да ову песму треба написати у дистисима, како би успорио низање трагичних микро-слика. А поменуте паузе и ауфтактови при гласном казивању приморавају читаоца да и са̂м обрати пажњу на музичке и сликарске валере дистиха.

Пратећи даље значењску и инхерентну музичку линију да̂ се уочити дискретни драматични crescendo са климаксом у четвртој строфи. Ова у себи садржи, и симбол (свећу), и боју (имагинарни жућкасти пламен), и посебан звук-тремол (тихо агонијско пуцкетање готово сагорелог фи- 
тиља). Завршне две строфе у истом тоналитету поступно се diminuendo претварају у недефинисану слику самрти, чија је доња ивица засенчена благим потезом необојене pianissimo исказане музичке мисли.

У издању „Гласа”, поводом стогодишњице Јакшићеве смрти, ова је песма штампана дводелно. Не знамо да ли је то случајно или је млади научник Иванић ову песму сложио према Јакшићевом рукопису? Ако би ово друго било тачно, онда бисмо имали још више разлога да у овако графички распоређеним стиховима видимо и својеврсну музичку структуру засновану на принципу proposta-risposta.

У сваком случају, ова једнотематска дводелна песма има своја два психолошка пиктурална и музичка климакса, и завршава се једном проширеном кодом у десетерцу, у којој два базалтна придева - „црнојзи” и „тешкојзи” - као да чине темељ заједно са осталим речима, темељ једног посмртног споменика. Ову компарацију са спомеником не би требало узети као израз моје способности за асоцијације. Извор „инспирације” пре би се могао наћи у чињеници да се у одређеним музичким облицима могу уочити аналогни архитектонски облици, као што у одређеним сликарским остварењима лежи нека музичка структура. Када се сетимо шта је Рембрант (омиљени Ђурин сликар) писао о људској фигури, кругу, троуглу, пирамиди, онда наше асоцијације споменика и других симболичких фигура нису ни најмање произвољне. Шта више, видећемо доцније, када будемо говорили о сликарским елементима у Јакшићевој поезији и обратно, од колике су важности ове геометријске и архитектонске структуре.

И песма Мила занимљива је с гледишта музике. Може се с правом рећи да она представља својеврсни рондо, што су уочили поједини композитори који су је углазбили. Да ли је овај облик Јакшић узео инспиришући се средњовековним шансонама или му је ова виртуозна форма, намењена првенствено за клавир, дошла преко уха, када је у Бечу, у породици Харитона Јоановића и код других слушао овакве и сличне композиције?

Ђурин песнички рондо, у којем контрастирају веселост и резигнација, припада ронду „са једном темом” и епизодама, које повезују и сенче основну тему. Рондо овог типа има на крају рефрен, као што је случај у овој Јакшићевој песми. Но ова песма није само занимљива по својој усковитланој, у тричетвртонском такту исказаној музици, већ и по начину како је лик ове мале крчмарице постао протејски и, такорећи, митски. Једино што је материјализовано у овој песми од Милине сфумато силуете, јесу њене мале руке. Руке, врло значајни симбол у Јакшићевом сликарству. 
Захваљујући Јакшићевој музичкој маштовитости ова мала крчмарица постаје „Аретејева птица”, симбол женске недостижности, „гетеовско вечно женско". Песник ће настојати да стихом, звуком и бојом, на импресионистичко-симболистички начин дочара њену неухватљивост. Ђурин дечачки синдром љубави оставио је дубоки траг на његовом стваралаштву, до границе својеврсног мазохизма. Али то је посебно деликатна тема о којој би ваљало неком другом приликом говорити. За сада истакнимо као најбитније: овај рондо о Мили као трослојна песма штедра је естетским доживљајем; и својеврсном музичношћу и пиктуралношћу дочарава сетну верленовску симболику „сентименталног разговора”.

Тема крчмарице час се јавља у аполинијском, а час у дионизијском тоналитету. Први се манифестује у песмама: Шma ћe, Пуста је, Да л’ mo, Љубав и др. Други пак принцип се исказује у великој мери у песмама: $\mathrm{Ha}$ ноћишту, Ал'ми сада, Моја Милка и др. У неким песмама се оба принципа стапају стварајући једну посебну атмосферу поетског еротизма. То најбоље илуструју песме: Ти си била, Сунще, Кроз поноћ... и др.

И управо због те своје инхерентне музичности Јакшићева поезија је лако певљива и привлачна за композиторе, од Даворина Јенка па до данас. За ову прилику навешћемо следеће примере: Бинички је компоновао На Липару као музичко-поетски рондо. Крстић је исту песму углазбио инсистирајући на тамном колориту, који је прошарао пасторалним зовом кларинета.

Док је први настојао да изрази ехо народског у архајској форми ронда, други пак више води рачуна о атмосфери, коју исказује контрастом тамних и ведрих тонова.

Рајичић је одабрао следећих пет песама: Пијем, Спомен, Милка, Вече, Поноћ. Оне представљају пет аспеката Ђуриног песничког и херојскомученичког живота. И оне као да представљају философско-поетски и полифонијски тестамент, јединство личног и општег.

Рајичић прву песму разрешава у експресивном ариозу, друга је у знаку контраста, поетског и музичког, сва у темпу marcia funebre. Tpeћa je scherzoso con malincolia. Четврта је својим значењима и звучањима упутила композитора на известан музички миметизам, ономатопејство, облик ронда са једним наглашеним контрастом. У петој, како је то истакао Перичић, долази до „највећег изражаја ауторов смисао да психолошки продуби поетску потку, налазећи одговарајући музички израз за нестварну атмосферу појаве сени песникове мајке и његов болни монолог, завршен резигнацијом".

Ови изабрани примерци Јакшићевих песама дају нам јаки повод да закључимо: Ђурина унутарња музичност и колоризам узет са роман- 
тичарске палете, били су привлачни за оне композиторе који су и сами неговали својеврсни романтичарски и неоромантичарски стил. Отуда су Ђурини стихови нашли у поменутих композитора адекватни израз. Међутим, Рајичић иде корак даље у истраживању музичког израза и под утицајем „прашке школе” настоји да у својој модерној „апартној оркестрацији", политоналним комбинацијама, како је то већ уочено, ипак сачува један призвук нашег фолклора.

Међутим, Јакшићева поезија је неким својим својствима блиска и модерном сензибилитету. То је осетио, поред осталих и Миленко Пауновић написавши своју Југословенску симфонију инспирисану Јакшићевом песмом На Липару. Вагнеровац Пауновић је осетио све богатство Јакшићеве конфликтности у судару поетских мотива, расположења, музичко-сликарских контраста, и у својој симфонији исказао све то богатом музичком палетом. А кроз све то провлачи се као cantus firmus мотив судбине.

Да је Јакшићева поезија слојевита, колористички и музички штедра и савремена, сведочи нам чињеница да су и друге његове песме нашле своје музичке тумаче код антитрадиционалиста. Тако се Душан Костић ослобађа позно-романтичарске традиције и трага за новим изразом у зони додекафоније и Хиндемитове музичке естетике. Тајчевић врло танано и дубоко трага за новим музичким вредностима песничке речи, за новим односом значења и звучања.

Анализа музичких својстава Јакшићеве поезије показује у највећем броју примера да се спољне форме не могу одвојити од унутарњих музичких структура нити се свеукупност његових поетско-музичких звучања могу одвојити од вредности пластичних валера и вишеслојних мисаоних значења.

Отуда и истраживање сликарских и других колористичких елемената у Јакшићевој поезији мора се такође вршити у светлости Јакшићевог сликарства да бисмо боље видели како се poeta и pictor допуњавају, али како и један и други настоји да сликар не постане пуки илустратор поезије и да овај опет не изгуби своју флуидност и музичност, понесен бојом и тачним цртежом.

Најпре пођимо од онога што је између песника и сликара заједничко, а што се можда мање бар у поезији запазило. Врло је танано уочено од стране уметничких критичара и историчара уметности (Коларић, М. Јовановић, Лаза Трифуновић) да је претежан део Јакшићевих слика грађен на рембрантовском пирамидалном принципу са дијагоналним експозицијама. Као примери, наведене су слике: Бакљада кроз Стамбол капију, Убиство Карађорђа, Устанак Црногораца и др. Нама се чини, и 
то са доста разлога, да се пирамидални принцип појављује у градњи херојских песама, као што је он функционалан и у сликању историјских и херојских призора. Погледајмо само песму Отацбина, па да се у то веома уверимо. Чак и сам песник каже: „А камен овај к’о пирамида”. Исто тако тамо где треба истаћи атмосферу и дух елевације, Јакшић (свесно или спонтано, у сликарству је то чинио свесно) прибегава пирамидалној структури (Пут у Горғак, Ноћ у Горњаку, Вече, Орао).

Контрастивност је не мање битан елемент Јакшићевог сликарства, али и његовог песништва. Но Јакшићево коришћење контраста у овим доменима уметности ретко кад има игоовску патетичност или делакроовску колористичку усковитланост и контрастне сударе космичких размера. Јакшићев прометејски дух сигурно би се усудио да свом душевном паклу да монументалне димензије, али за то није имао ни времена, ни платна, ни „пемзле”, па ни довољно знања. Чак и у драмској поезији, где је ту силину судара и драмске конфликтности могао више да испољи, био је више епичар и лирик, него драматичар.

Занимљиво је проверити да ли проблем осветљења и таме Јакшић слично разрешава као и у сликарству. Основна контрастирања светлог и тамног, пламеног и мрачног, златног и црвеног, Ђура Јакшић користи обилато, што је већ довољно уочено. Но да ли и у неким Јакшићевим песмама можемо наћи три извора осветљавања, као у Бакљади, или унутарња исијавања светлости, као у слици Убиство Карађорђа?

У вези са тим, указујемо на Трифуновићев тачан закључак да се разни видови осветљавања налазе, и у сликарству, и у поезији. „Јакшић - истиче Трифуновић - воли ноћ и ватру, разуме их, зна да их претвори у боју, сочну и густу, запаљену изнутра. Оваква концепција светла омогућила је да се постигне пун колористички звук и истакне лепота материје и фактуре”.

Пригушено светло налази се веома сликарски употребљено у песми Спомен. Оно има већ овде три извора: свећу, кандило и дан. У песми Вече спољне светлости су сунце и месец као комплементарне светлости. Унутарња светлост постоји у поеми Ноћ у Горюаку. Светлост која зрачи из песника; то је огањ, унутарњи сагор бескрајног очаја. Дакле нестварна, нефизичка светлост. И она мистериозна светлост, као путир светога Грала, која избија из беле куле у Горњаку и „светитељска светлост”, при походу цара Лазе Горњаку. У овим песмама и другим, као и у Јакшићевом сликарству, присутна је често светлосна структура, која оживљава слику из два супротна угла или из центра.

Иако је помоћу тих осветљавања и затамњења, јер код Јакшића постоје нијансе тамних светлости, уметник постизао веома снажне коло- 
ристичке ефекте, ипак не треба заборавити да је у дну и сликарског и поетског језика лежала скривена вишеслојна порука.

Начин коришћења боја такође је нешто заједничко од Ђуре песника и сликара. Само, не би се могло рећи да су боје у подједнакој палетској разуђености и у једној и у другој уметности. У сликарству, иако је често доминантна црвена боја, са свим њеним преливима, те наговештене нијансе видљиве су при ближем гледању, посматрању и увек, и кад су смирене, пулсирају једном скривеном узнемиреношћу. У поезији је друкчије. Овде су боје дате такорећи чисте, из тубе, и са много мање нијанси. У сликарству као да се Јакшић бојао разуларених пламенова и превеликог шкргута зуба (његове и ратничке слике нису драстично исцерене и искрвављене) док је у поезији више звучног пламсања, а мање четврттонских прелива. Боје су и ту и тамо дурске, а кад су и пригушене, молске, не губе се у водњикавом, избледелом лиризму ни трогателној, јефтино обојеној драматици. Ту је више заслуга утицаја Рембранта и низоземске школе, а мање Рубенсове усковитланости и запаљености.

Ваљало би говорити о проблему деформације, асиметричности, сликарским и песничким недореченостима, које нису, у највећем броју случајева, израз невештине већ потребе за експресивношћу. Да̄ се утврдити да су извесна згушњавања и разређивања боја у сликарству и поезији израз жеље да се истакну битности, да се осветли или затамни једна слика како би постала изразитија и ефекат већи. Али Јакшић није никад ишао за ефектом ради ефекта, није давао примат форми над садржином, боји над звучањем и значењем. Зато помало чуди кад се у говору о сликарству истиче како је Јакшић хтео у овој или оној слици да разреши проблем светлости и сенке, питање пиктуралности као такве. Слажемо се да је било више размишљања кад је сликао, али је увек најбоље сликао кад би се понео више осећањем а мање интелектом. То важи, и у сликарству, и у поезији.

Познато је, а то и сам Ђура каже, да се мучио са пејзажем, да му је недостајало знања. То је доста тачно. Али чињеница је да и кад је у довољној мери савладао у Бечу техничка знања, његов је пејзаж остао готово занемарљив. Нарочито тамо где је био фон, најављујући се у једном затамњеном и дифузном тоналитету. И у највећој мери зато, јер Јакшић није волео „бидермајерске лизане манире”, како би рекао Вељко Петровић, нити пејзаже-штафаже који не доприносе да се стожерни проблем и тема максимално искажу.

Да је пејзаж био строго функционалан, подређен основној идеји, сведоче његове већ толико познате поеме, као што су Пут у Горғак, Ноћ у Горнаку, Поноћ и др. 
Али ваља водити рачуна и о оним пејзажима и бојама који су се изнедрили из непосредне доживљености, а не из атељеа, и тиме добили чак неки а̂ло симболизма и реалистичног романтизма. И управо због тих сликарских и музичких нијанси, треба још много трагати да би се осетило колико нам је Јакшић близак и колико је модеран. Модеран по иронији, по гротески, по наговештеном зеленом и црном хумору.

Ако у Ђурином сликарству немамо бошовских гримаса и гојинског Галгенхумора, у његовим појединим песмама и кратким причама извире хумор као из Домијеових цртежа. Зар није за то убедљив пример песма посвећена „Јевропи”?

Због тог нервозног и полифоног сензибилитета, те раздртости, Ђура је близак нашем времену - наш сапатник, проклетник и прогоњени Прометеј, који се бранио сликом, стихом и музиком тражећи излаза из очајања, из пакла у којем је живео, како је слично рекао Лазар Трифуновић.

Radoslav Josimović

LES ÉLÉMENTS MUSICAUX ET PICTURAUX DANS LA CRÉATION ARTISTIQUE DE ĐURA JAKŠIĆ

Résumé

Lauteur de cette étude a traité de quelques problèmes essentiels, notemment:

1. La structure polymorphe musicale propres à maints poèmes de Jakšić;

2. La structure pyramidale caracteristique pour ses tableaux se manifeste aussi dans sa poèsie;

3. Analyse des partitions musicales faites sur les vers de Jakšić.

Dans ces analyses Josimović a mis en relief le talent polyphonique de Jakšić qui fut musicien et peintre en poèsie et poète et musicien dans son art pictural. 